粗面上の粒子の浮遊機構

Mechanism of Particle Suspension

$\begin{array}{llllll}\text { 京都大学防災研究所 } & \text { 正員 } & \text { 芦 } & \text { 田 } & \text { 和 } & \text { 男 } \\ \text { 京 都 大学大学院 } & \text { 学生員 } & \text { 藤 } & \text { 田 } & \text { 正 } & \text { 治 } \\ \text { 京都大学工学部 } & \text { 学生員 } & \text { 向 } & \text { 井 } & & \text { 健 }\end{array}$

\title{
1. 緒譶
}

河川中上流域においても，混合粒径の河床砂喽の中にかなりの細粒成分が含まれているてとが多い。ての 細粒成分の土砂は主として浮遊砂として流送されるので, 流出土砂量の算定や河床変動の問題を取り扱う場 合には，粗面上の粒子の浮遊砂量を推定するてとが必要である。

粒子の浮遊砂量の推算式に関する研究はてれまで多くあるが, 浮遊機構を詳細に検討しているものは少な い。著者ら ${ }^{1)}$ は精度の良い浮遊砂量式を求めるために, 浮遊機構に関する研究を行っているが, いままで, 粒子の運動と流れとの関連を直接計測しておらず, 粒子を浮上させる外力が何であるかなど不明確な点があ った。そてで, 本研究では, 流れを可視化して河床付近の流れと粒子の浮遊運動を同時に高速ビデオ撮影し て, 浮遊機構を詳細に議論する。また, その検討結果より, 浮遊機構を定式化するとともに, その成果を用 いて粗面上の粒子の浮避限界を理論的に明らかにする。

\section{2. 粗面河床付近の流れと浮遊機構}

粗面河床上の粒子の浮遊機構を明らかにするために，次に述べ るような実験により, 河床付近の流れの特性と粒子の浮遊現象と の関連性を詳細に検討した。

\section{2-1 実験方法および条件}

実験水路は幅 $30 \mathrm{~cm}$, 長さ $8 \mathrm{~m}$, 勾配 $1 / 1000$ であり, 河床には 粒径 $d_{r}=0.48 \mathrm{~cm}$ の礫が均一に敷かれている。底面付近の流れの特

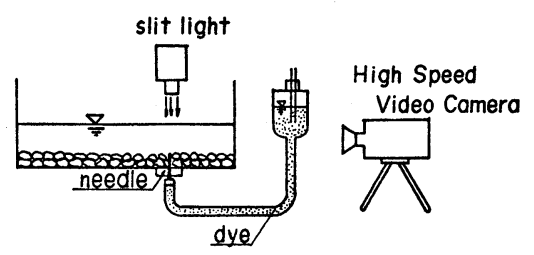
性を調べるため, 水路上流端から $5 \mathrm{~m}$ の位置に, 外径 $1 \mathrm{~mm}$ の注射針を水路の下から鿬の頂部付近まで差し込 み, 図ー 1 に示すような装置で染料（ローダミンB）を一定速度で河床面に供給できるようにした。

実験は, 流量 $Q=1.2 \mathrm{l} / \mathrm{s}$, 水深 $h=2.8 \mathrm{~cm}$, 摩擦速度 $u_{*}=1.53 \mathrm{~cm} / \mathrm{s}$, 砂粒レイノズル数 $R_{*}\left(=u_{*} d_{r} / \nu\right)=$ 73 ( $\nu$ : 動粘性係数) の条件で行われ, 染料で可視化された河床付近の流れと, 上流から供給された粒径 $0.14 \mathrm{~cm}$, 比重 1.05 のポリスチレン粒子の運動を, 図ー 1 に示すようにスリット光線を照射して高速ビデオ （1フレーム $1 / 200$ 秒で再生可）で同時に撮影した。染料の鉛直方向の注入速度は, 実験と同じ水深の静 水中に染料を注入して調べた結果，あまり大きくなく，鉛直方向の乱れに対する注入による影響はほとんど ないものと思われる。また, 実験に際し, 水路内に置かれたスケールを撮影し, それを用いて粒子の軌跡を 求めた。

\section{2-2 河床付近の流れと浮遊現象}

写真一 1，2 は, 粒子の運動と河床付近の流れとの関連を連続写真で示したもので, 写真中の白く丸いも のがポリスチレン粒子, 河床上の不定形のものが染料であり, 上方の数值は撮影時刻 (1/1000 秒単位)を 表わすものである。また，図一－2(a)，（b)，（c）は，浮遊粒子の飛行高さ $z_{p}$ と，粒子に作用する鉛直方向の 流体力 $F_{D}$ の時間変化を示したものである。 $F_{D}$ は次章で述べる運動方程式 (9) 式と粒子の軌跡から求めた。

最初に，てれらの写真や図から，粒子が河床を離脱する過程について考察しょう。写真－1に見られるよ うに，粒子は流体塊とともに急激に持ち上げられ河床を離脱し（（a），(b)），その流体塊の影響をうけなが ら,さらに浮上している( (c))。離脱時に粒子に作用する力は, てのような現象から判断すると河床付近で 

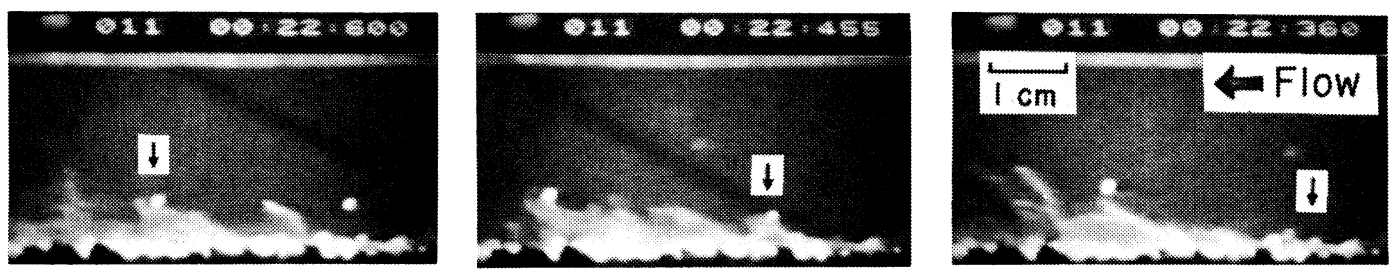

写真 - 1 河床付近の流れと粒子の離脱過程

（右加ら (a)，(b)，(c) )
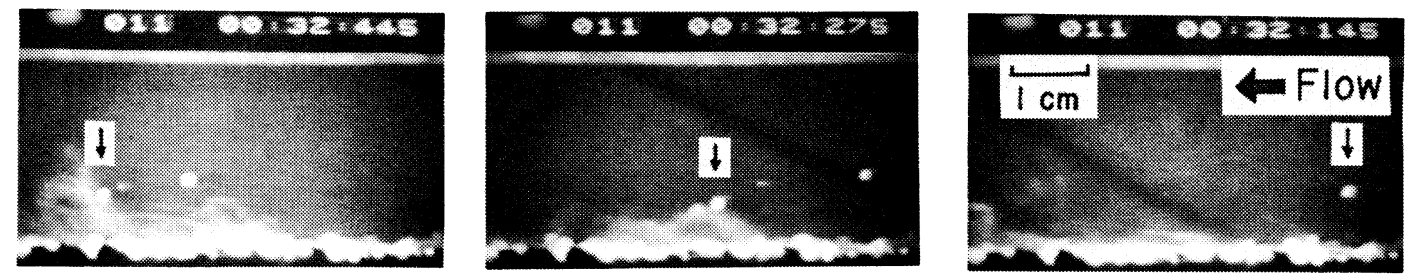

写真 - 2 河床付近の流れと粒子の再浮上過程 （右から（a），(b)，（c））

生じる揚圧力であり, 河床面との衝突による反発力ではない。 離脱後初速 $w_{p_{0}}$ を得た粒子は, 図一 2 に示すようにかなり大きい 流体力の作用によりさらに浮上していろ。すなわち，離脱後の 粒子の運動は $w_{p_{0}}$ によってのみ決まるのではなく，粒子ととも に上昇する流体塊による流体力の影響をうけて決定されること がわかろ。流体力は，上昇する流体塊の寿命時間を過ぎると急 激に減少し, 粒子はやがて沈降し始めろ。

ついで，浮遊粒子が再浮上する過程について考察する。沈降 し始めた粒子には，図－2（b），(c) のように再浮上するものと 図-2（a）のように着床するものがある。写真 - 2 は前者の場 合を示したもので，上流から流下沈降してきた粒子が，河床付 近で発生した上昇する流体塊の影響をうけて( (b)), 再浮上し ていろ ( (c))。また, 再浮上時には, 図一 2(b), (c)に示すよ
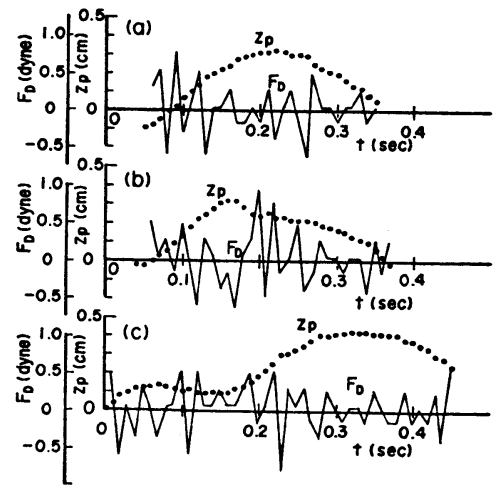

図-2 粒子の飛行高さと粒子に作用す ろ流体力の時間変化

うに，大きな流体力が急激に作用しており，粒子は上昇流によ

ろ流体力により再浮上していることがわかる。一方, 沈降中に流体力が作用しない場合は, 図一2（a）のよ うに再浮上せず着床する。

てのように，粒子の浮遊現象は河床付近で生じろ上昇流の影響を強くうけていろが，ての上昇流は間欠的 に生じる強い乱れであり, Grass ${ }^{2)}$ や蛹津 ${ }^{3}$ が水素気泡を用いた可視化実験で観察した粗面乱流でのエシェク

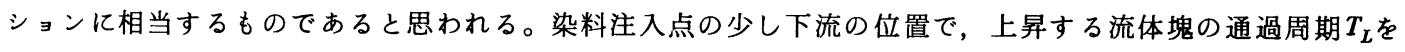
を測定し，外部パラメータで無次元化した值で示すと $\bar{T}_{L} u_{\max } / h \fallingdotseq 2\left(u_{\max } ;\right.$ 最大流速, $\bar{T}_{L} ; T_{L}$ の平均値) であった。滑面におけるバースティングの平均周期 $\bar{T}_{B}$ の無次元表示は, 中川, 禰津 ${ }^{4}$ によると $\bar{T}_{B} u_{\max } / h=$ 1 〜 3 であるので, $T_{L}$ と $T_{B}$ はほほ等しい值である。したがって, 本実験のような粗面河床でも， $T_{B}$ と同じ オーダーの周期でェジェクションが生起しており, 粒子の浮遊現象はてれの影響を強くうけていると考えら れる。

$2-3$ 粒子の浮遊機構

2-2で検討した結果より，粒子の浮遊機構は次のようであると考えられる。粗面においてもほほ滑面の バースティング周期と同じォーダーの周期で, 河床付近でェシェクションが生起し, それに伴って鉛直方向 
の強い上昇流が生じるとともに，粒子は揚圧力の作用で河床を急激に離脱する。河床を離脱した粒子は，同 時に発生した上昇する流体塊から流体力をうけて, さらに浮上する。流体塊の寿命時間が過き流体力が減少 すると, やがて粒子は沈降し着床する。沈降する過程で, エジュションによる上昇する流体塊から再び強 い流体力をうけると粒子は再浮上する。てのように, 粒子の浮遊機構では, 揚圧力と上昇する流体塊からう ける流体力とその作用時間（寿命時間）が重要であり，次章でてれらの力や作用時間を評価して浮遊機構を モデル化し，粒子の浮遊運動を解析する。

\section{3. 粒子の浮遊機構に関する理論}

\section{$3-1$ 浮遊機構のモデル}

2 章で得られた知見から，浮遊機構を鉛直方向に関し て次のようにモデル化する。（図ー 3 参照）

(i) 河床の粒子に揚圧力 $F_{L 0}$ が $t *$ 時間作用し, 粒子は 時刻 $t=0$ に初速 $w_{p_{0}}$ で河床を離脱する。

（ii）河床を離脱した粒子には，同時に発生した鉛直方 向速度 $w_{f}$ の上昇流による流体力 $F_{D}$ がその寿命時間 $t_{e}$ の

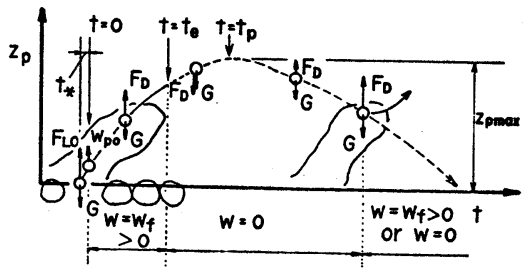
間作用して，粒子は浮上する。

(iii) $t=t_{e}$ で上昇流が消滅し， $t>t_{e}$ では粒子に作用する流体の鉛直方向速度は 0 となる。とのとき, 粒 子の上昇速度は减速して, $t=t_{p}$ において 0 となり, 重力の作用により河床へ沈降する。

（iv）沈降の過程で鉛直方向の速度 $w_{f}$ の上昇流が粒子に作用すると，再び $F_{D}$ がその寿命時間 $t_{e}$ の間作用し， 再浮上する。

\section{$3-2$ 浮遊機構の定式化}

ここでは，3-1の(iV)の過程は(ii) の過程と同様の解析となるので（i)〜 (iii) の過程について解析する。

(1) 粒子の鉛直方向の初速度 $w_{p_{0}}$ とその確率分布

てれに関しては著者らの研究 ${ }^{1)}$ 亿解析されており, 詳しい説明は省略する。平均 0 , 標準偏差 $F_{L 0}{ }^{\prime}$ の正規 分布で与えられる揚圷力 $F_{L 0}$ が $t_{*}=\alpha d / w_{p_{0}}$ （実験より $\alpha=1 ）$ の間作用するとすると, $w_{p_{0}}$ とその条件 $\left(w_{p_{0}}\right.$ $>0 ）$ 付確率密度関数は (1), (2) 式で表わされる。

$$
\begin{aligned}
& w_{p 0}=\sqrt{a_{3}\left(F_{L 0}-G\right)} \\
& f_{w_{p 0}}\left(w_{p 0}\right)=\frac{2 w_{p 0}}{\sqrt{2 \pi} F_{L 0}^{\prime} a_{3}} \exp \left\{-\frac{1}{2} \frac{\left(w_{p 0}{ }^{2} / a_{3}+G\right)^{2}}{F_{L 0}{ }^{2}}\right\} / \int_{G}^{\infty} f_{F_{L 0}}\left(F_{L 0}\right) d F_{L 0} \cdots \cdots
\end{aligned}
$$

こてに, $a_{3}=6 /\left(\pi d^{2} \sigma\right), G:$ 水中重力である。また, $F_{L 0}^{\prime}$ は $F_{L 0}^{\prime} \propto \rho w^{\prime 2} \cdot d^{2}\left(w^{\prime}:\right.$ 鉛直方向の乱れ強度) および粗面での碟の遮蔽効果を考慮した $w^{\prime}=k u_{*}(k:$ 遮蔽係数) の関係を用いると（3）式となる。

$$
F_{L 0}^{\prime}=c k^{2} \rho u_{*}^{2} d^{2}(c: \text { 比例係数) }
$$

(2) 離脱後の粒子の運動

Tchenによる粒子の鉛直方向の運動方程式である(4)式を用いて, 離脱後の粒子の運動を解析する。

$$
\frac{\pi}{6} d^{3}(\sigma-\rho) \frac{d w_{p}}{d t}=F_{D}+F_{L}+\frac{1}{2} \frac{\pi}{6} d^{3} \rho\left(\frac{d w}{d t}-\frac{d w_{p}}{d t}\right)-G
$$

こと， $d:$ 粒径， $\sigma, \rho:$ 粒子おょび流体の密度， $w_{p}, w:$ 粒子おょび流体の鉛直方向の速度である。

(4) 式中の $F_{D}, F_{L}, G$ は粒子に働く流体力, 揚圧力および水中重力で(5)〜（7) 式で表示される。

$$
\begin{aligned}
& F_{D}=\frac{1}{2} \rho C_{D}\left|w-w_{p}\right|\left(w-w_{p}\right) \frac{\pi}{4} d^{2} \ldots \ldots . \\
& G=(\pi / 6) d^{3}(\sigma-\rho) g \quad \cdots \cdots \cdots \cdots \cdots \cdots . . .
\end{aligned}
$$$$
F_{L}=\frac{\pi}{6} d^{3} \rho\left(\frac{d w}{d t}-\frac{d w_{p}}{d t}\right)
$$

こてに， $C_{D}$ : 抵抗係数で Rubey の半理論式を適用すると（8)式で表わされる。 


$$
C_{D}=2+24 / R_{e} \quad\left(R_{e}=\left|w-w_{p}\right| d / \nu\right)
$$

ことに, $R_{e}:$ レイズル数, $\nu:$ 動粘性係数である。

著者らの研究 ${ }^{1)}$ によると， $F_{L}$ は粒子が河床を離脱した後急激に減少し 0 となるととが明らかにされてお り,ててでも $F_{L}=0$ とおくと,(4) 式は次式のように変形される。

$$
(\pi / 6) d^{3}(\sigma+\rho / 2) d w_{p} / d t=F_{D}-G
$$

(9)式を次の初期条件と $w$ の条件のもとで解けば $w_{p} や z_{p}$ の時間変化が求められる。

$$
\begin{aligned}
& t=0 ; w_{p}=w_{p_{0}}, z_{p}=a_{1} d \\
& 0<t \leqq t_{e} ; w=w_{f}(>0), t>t_{e} ; w=0
\end{aligned}
$$

こてに， $a_{1} d: F_{L 0}$ が作用する厚さで，著者らの研究 ${ }^{1)}$ てると $0.5 d$ である。

（9）式を解くと， $w_{p_{0}}, w_{f}, t_{e}$ の值に応じて色々な解がでてくるが，乙てでは代表的な例として，3-1で 述べたような場合，すなわち， $w_{p_{0}}<w_{f}, w_{f}-w_{0}>0$ (こてに, $w_{0}$ : 粒子の沈降速度）， $t_{p}>t_{e}$ の場合 について, $w_{p} や z_{p}$ の解析結果を示すととにする。

(i) $0 \leqq t \leqq t_{e}\left(w=w_{f}>0\right)$ のとき

$2 A_{1} w_{p}+B_{1}+p_{1} \geqq 0$ の場合（離脱後 $w_{p}$ が減小し， $w_{f}-w_{0}$ に近つく場合）

$$
w_{p}(t)=-\frac{B_{1}}{2 A_{1}}+\frac{p_{1}}{2 A_{1}} \frac{1-\mathrm{e}^{p_{1}\left(t+D_{1}\right)}}{1+\mathrm{e}^{p_{1}\left(t+D_{1}\right)}} \cdots \text { (12) } \quad z_{p}(t)=-\frac{B_{1}}{2 A_{1}} t+\frac{1}{2 A_{1}} \ln \frac{\mathrm{e}^{p_{1}\left(t+D_{1}\right)}}{\left\{1+\mathrm{e}^{\left.p_{1}\left(t+D_{1}\right)\right\}^{2}}\right.}+D_{2} \cdots
$$

$2 A_{1} w_{p}+B_{1}+p_{1}<0$ の場合（離脱後 $w_{p}$ が増加し, $w_{f}-w_{0}$ に近づく場合）

$$
w_{p}(t)=-\frac{B_{1}}{2 A_{1}}+\frac{p_{1}}{2 A_{1}} \frac{1+\mathrm{e}^{p_{1}\left(t+D_{1}\right)}}{1-\mathrm{e}^{p_{1}\left(t+D_{1}\right)}} \cdots \cdots \quad \text { (14) } \quad z_{p}(t)=-\frac{B_{1}}{2 A_{1}} t+\frac{1}{2 A_{1}} \ln \frac{\mathrm{e}^{p_{1}\left(t+D_{1}\right)}}{\left\{\mathrm{e}^{p_{1}\left(t+D_{1}\right)}-1\right\}^{2}}+D_{3} \cdots
$$

ととに, $A_{1}=\frac{3}{2 d} \frac{\rho}{\sigma+\rho / 2}, B_{1}=-A_{1}\left(2 w_{f}+\frac{12 \nu}{d}\right), C_{1}=A_{1}\left(w_{f}^{2}+\frac{12 \nu}{d} w_{f}\right)-\frac{\sigma-\rho}{\sigma+\rho / 2} g, p_{1}=\sqrt{\left|B_{1}^{2}-4 A_{1} C_{1}\right|}$, $D_{1}=\frac{1}{p_{1}} \ln \left|\frac{2 A_{1} w_{p_{0}}+B_{1}-p_{1}}{2 A_{1} w_{p_{0}}+B_{1}+p_{1}}\right|, D_{2}=a_{1} d-\frac{1}{2 A_{1}} \ln \frac{\mathrm{e}^{p_{1} D_{1}}}{\left(1+\mathrm{e}^{p_{1} D_{1}}\right)^{2}}, D_{3}=a_{1} d-\frac{1}{2 A_{1}} \ln \frac{\mathrm{e}^{p_{1} D_{1}}}{\left(\mathrm{e}^{p_{1} D_{1}-1}\right)^{2}}$ である。

(ii) $t_{e}<t \leqq t_{p}$ のとき $(w=0)$

$t=t_{\boldsymbol{e}}$ で $w_{p}=w_{p_{e}}, z_{p}=z_{p_{e}}((\mathrm{i})$ で計算される。）の条件で(9)式を解くと，次のようになる。 $B_{2}^{2}-4 A_{2} C_{2} \geqq 0$ の場合 $\left(d \leqq \sqrt[3]{54 \nu^{2} /\{(\sigma / \rho-1) g}\right\}$ の場合)

$$
w_{p}(t)=-\frac{B_{2}}{2 A_{2}}+\frac{p_{2}}{2 A_{2}} \frac{1+\mathrm{e}^{p_{2}\left(t+E_{1}\right)}}{1-\mathrm{e}^{p_{2}\left(t+E_{1}\right)}} \cdots \cdots \text { (16) } z_{p}(t)=-\frac{B_{2}}{2 A_{2}} t+\frac{1}{2 A_{2}} \ln \frac{\mathrm{e}^{p_{1}\left(t+E_{1}\right)}}{\left\{\mathrm{e}^{p_{1}\left(t+E_{1}\right)}-1\right\}^{2}}+E_{2}
$$

$B_{2}^{2}-4 A_{2} C_{2}<0$ の場合, $\left(d>\sqrt[3]{54 \nu^{2} /\{(\sigma / \rho-1) g\}}\right.$ の場合 $)$

$$
w_{p}(t)=-\frac{B_{2}}{2 A_{2}}+\frac{p_{2}}{2 A_{2}} \tan \left\{\frac{p_{2}}{2}\left(t+E_{3}\right)\right\} \cdots \cdots \text { (18) } z_{p}(t)=-\frac{B_{2}}{2 A_{2}} t-\frac{1}{A_{2}} \ln \left|\cos \frac{p_{2}}{2}\left(t+E_{3}\right)\right|+E_{4}
$$

こてに, $A_{2}=-\frac{3}{2} \frac{1}{d} \frac{\rho}{\sigma+\rho / 2}, B_{2}=A_{2} \frac{12 \nu}{d}, C_{2}=-\frac{\sigma-\rho}{\sigma+\rho / 2} g, p_{2}=\sqrt{\left|B_{2}^{2}-4 A_{2} C_{2}\right|}$,

$E_{1}=\frac{1}{p_{2}} \ln \frac{2 A_{2} w_{p e}+B_{2}-p_{2}}{2 A_{2} w_{p e}+B_{2}+p_{2}}-t_{e}, E_{2}=z_{p e}+\frac{B_{2}}{2 A_{2}} t_{e}-\frac{1}{2 A_{2}} \ln \frac{\mathrm{e}^{p_{2}\left(t_{e}+E_{1}\right)}}{\left\{\mathrm{e}^{p_{2}\left(t_{e}+E_{1}\right)}-1\right\}^{2}}, \quad E_{3}=\frac{2}{p_{2}} \arctan \left(\frac{2 A_{2} w_{p e}+B_{2}}{p_{2}}\right)$

$-t_{e}, E_{4}=z_{p e}+\frac{B_{2}}{2 A_{2}} t_{e}+\frac{1}{A_{2}} \ln \left|\cos \frac{p_{2}}{2}\left(t_{e}+E_{3}\right)\right|$ である。

また，最大飛行高さ $z_{p \max }$ とその時の時刻 $t_{p}$ は次式となる。

$$
\begin{aligned}
B_{2}^{2}-4 A_{2} C_{2} \geqq 0 ; & t_{p}=\left(1 / p_{2}\right) \ln \left\{\left(B_{2}-p_{2}\right) /\left(B_{2}+p_{2}\right)\right\}-E_{1} \\
& z_{p \max }=z_{p}\left(t_{p}\right)((17) \text { 式 }) \\
B_{2}^{2}-4 A_{2} C_{2}<0 ; & t_{p}=\left(2 / p_{2}\right) \arctan \left(B_{2} / p_{2}\right)-E_{3} \\
& z_{p \max }=z_{p}\left(t_{p}\right)((19) \text { 式 })
\end{aligned}
$$


(iii) $t>t_{p}$ のとき $(w=0)$

$t=t_{p}$ で $w_{p}=0, z_{p}=z_{p \max }$ の条件で(9) 式を解くと次のようになる。

$$
w_{p}(t)=-\frac{B_{2}}{2 A_{3}}+\frac{p_{3}}{2 A_{3}} \frac{1-\mathrm{e}^{p_{3}\left(t+F_{1}\right)}}{1+\mathrm{e}^{p_{3}\left(t+F_{1}\right)}} \cdots \cdots(24) \quad z_{p}(t)=-\frac{B_{2}}{2 A_{3}} t+\frac{1}{2 A_{3}} \ln \frac{\mathrm{e}^{p_{3}\left(t+F_{1}\right)}}{\left\{1+\mathrm{e}^{\left.p_{3}\left(t+F_{1}\right)\right\}^{2}}+F_{2} \cdots\right.}
$$

こてに, $A_{3}=-A_{2}, p_{3}=\sqrt{\left|B_{2}^{2}-4 A_{3} C_{2}\right|}, F_{1}=\frac{1}{p_{3}} \ln \left|\frac{B_{2}-p_{3}}{B_{2}+p_{3}}\right|-t_{p}, F_{2}=z_{p \max }+\frac{B_{2}}{2 A_{3}} t_{p}-\frac{1}{2 A_{3}}$

$\ln \frac{\mathrm{e}^{p_{3}\left(t_{p}+F_{1}\right)}}{\left\{1+\mathrm{e}^{p_{3}\left(t_{p}+F_{1}\right)}\right\}^{2}}$ である。

$3-3$ 浮遊運動に関する解析結果と実験結果との比較

図-4は， $F_{L 0}$ 亿関する研究成果 ${ }^{1)}$ より，(3) 式中の $c k^{2}$ の 值を 5.06 として, $w_{p_{0}}$ の頻度分布の理論值を求め, 実験值 ${ }^{1}$ と 比較したものである。理論值は実験值より分散が大きいが, 両 者はほぼ適合している。

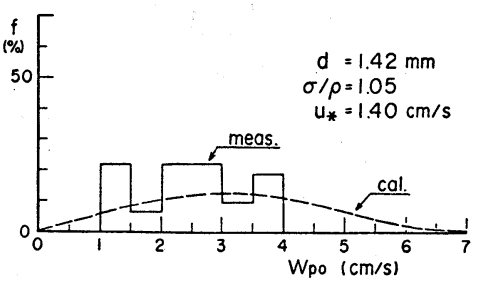

図一 5 は, 図- $2(\mathrm{~b}),(\mathrm{c})$ の $z_{p}, F_{D}$ の時間変化を前述の解析 に従ってシミュレートしたもので，(a) は河床から離脱する場 合，(b)は再浮上する場合を対象としている。 $w_{p_{0}}$ を軌跡から与え， 図ー5のように理論值と実験值がよく一致するときの $w_{f}$ と $t_{e}$ の值は, 図中に示すように, $w_{f}=6 \mathrm{~cm} / \mathrm{s}, t_{e}=0.05 \sim 0.07$ $\sec$ であった。可視化された上昇流をビデオ解析し, $w_{f} や t_{e}$ の 値を推定すると, $w_{f}=1 \sim 7 \mathrm{~cm} / \mathrm{s}, t_{e}=0.02 \sim 0.08 \mathrm{sec}$ であ り,てのととより, 本モデルの妥当性がうかがえる。

ついで，実河川で対象となるような $d=200 \mu, \sigma / \rho=2.65$ の粒子が河床を離脱するとき, 本研究のシミュレーションで, $w_{f}$ の值によってどのような運動をするのかについて検討する。 図-6は $w_{p_{0}}=3 \mathrm{~cm} / \mathrm{s}, w_{f}=0,1$ および $4 \mathrm{~cm} / \mathrm{s}, t_{e}=0.02 \mathrm{sec}$ として， $z_{p}$ の時間変化を求めたものである。なお， $w_{p_{0}}$ の平均 值が $3 \mathrm{~cm} / \mathrm{s}$ となるのは(2) 式から $u_{*} \fallingdotseq 4 \mathrm{~cm} / \mathrm{s}$ のときである。と の図上り，粒子の飛行高は $w_{f}$ の影響を強くうけ， $w_{f}$ が大きくな ると $z_{p \max }$ の值は急激に増加するととがわかる。 $w_{f} や t_{e}$ は確 率変数であり, $z_{p}(t)$ の值は図 -6 の $w_{f}=0$ の場合を最小值 として確率的に分布するが，乙れに関する検討は今後の課題と したい。

\section{4. 柤面上の粒子の浮遊限界}

粒子が河床を離脱する機構として，揚圧力によるものと河床 砂碰との衝突によるものが考えられる。揚圧力が作用するよう な場では, エシェクションによる上昇流が存在するので, 離脱

図-4 $w_{p_{0}}$ の頻度分布の実験値と理論 值の比較

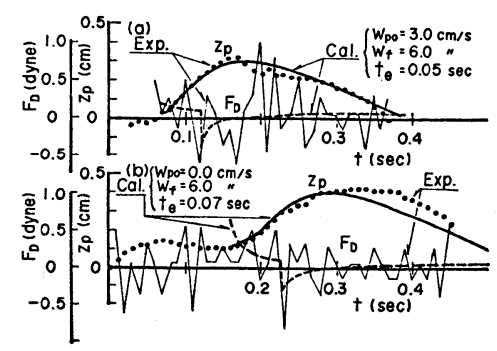

図-5 $z_{p}, F_{D}$ の時間変化の実験值と 理論値の比較

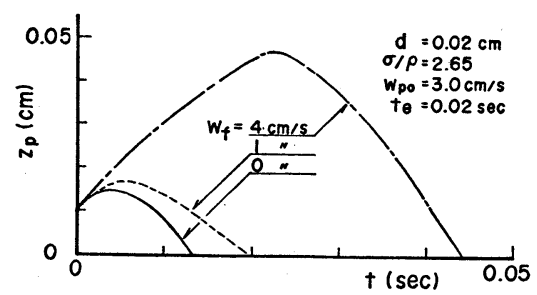

図-6 $\quad z_{p}$ の時間変化、级漂す $w_{f}$ の 影響 した粒子はての上昇流による流体力を受けて，かなりの高さま で浮上する。一方, 衝突による場合, 離脱した粒子は, 離脱時の初速によるサルテーション運動をし, 両者 で粒子の運動軌跡が非常に異なる。浮遊砂は上昇流によって浮上する粒子であるから，著者らは，粒子の浮遊 限界を粒子が揚圧力で河床から離脱する限界と定義するてとが妥当であると考える。

上述の定義に従うと，粒子の浮遊条件は， $F_{L_{0}}>G$ で与えられ， $F_{L_{0}}$ の確率分布を正規分布とすると，(3) 
式より, 河床の粒子が $P_{\alpha}\left(F_{L 0}>\alpha F_{L 0}{ }^{\prime}\right.$ となる確率 $)$ 以上の確率 で河床を離脱する条件は， $\alpha F_{L 0}{ }^{\prime} \geqq G$ となり, この条件の限界摩擦 速度 $u_{* s}\left(P_{\alpha}\right)$ は次式のようになる。

$$
\frac{u_{* s}\left(P_{\alpha}\right)^{2}}{(\sigma / \rho-1) g d}=\frac{\pi}{6} \frac{1}{\alpha c k^{2}}
$$

(26) 式中の $c k^{2}$ は $F_{L 0}$ や遮蔽係数に関する係数であり, 理論的に 求めることは困難である。そこで, 著者らの行った浮遊限界の実 験值 $^{5)}$ が $\alpha=3$ に対応するとして, $c k^{2}$ の值を推定し, それを $d /\left(d_{r}-a\right)\left(d_{r}\right.$ : 河床上の粗粒子の粒径, $a$ : 粒径 $d$ の粒子の堆 積厚）とdをパメラメータにして整理したものが図ー7である。 図一 7 より, $d \geqq 163 \mu$ では $c k^{2}$ が一定となることが推察される ので, $d /\left(d_{r}-a\right)=0.05$ と 0.15 の場合について, 図 -7 や著者 らの浮遊限界の理論解析 ${ }^{5)}$ を参考にして, $\alpha=3$ に対する浮遊限 界 $u_{*_{s}}(0.13 \%)$ を（26）式から求めると, 図一8のようになる。 図中には，参考のため沈降速度 $w_{0}$ や無次元限界掃流力 $\tau_{*_{c}}$ を表わ す曲線と $u_{* s}$ の実験值が示されている。

この図より，粒子が河床を離脱し始めるとき， $u_{*} d / \nu<2$ で は $u_{*}>w_{0}$ の条件となっており，かなりの高さまで浮上するのに 対し， $u_{*} d / \nu>2$ では, $u_{*}<w_{0}$ であり,離脱してもあまり浮上 しないてとが考察される。

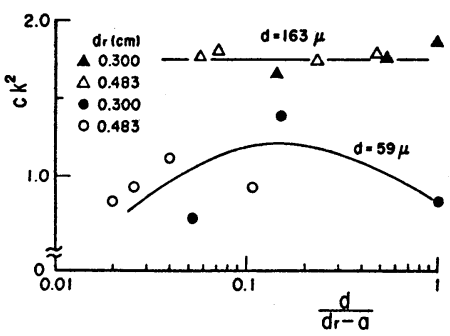

図 $-7 c k^{2}$ の値

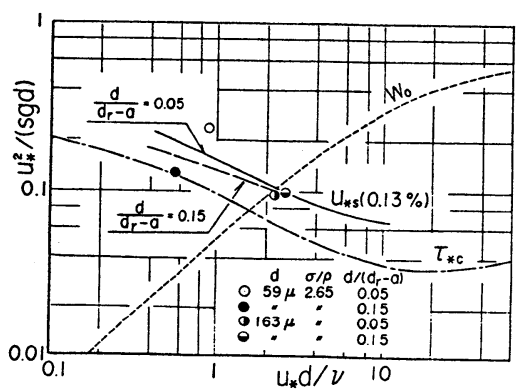

図-8 粗面上の粒子の浮遊限界

\section{5. 結 研}

以上, 粗面上の粒子の浮遊現象は河床付近で発生するエジェクションと関連があり，粒子はその際発生す る揚圧力によって河床を離脱し，同時に生じる上昇流による流体力によってさらに上昇することが明らかに された。また，そのような浮遊機構を揚圧力ゃ上昇流の流速とその作用時間（寿命時間）を与えて定式化し て, 粒子運動の軌跡を解析する理論式を提案し, 飛行高の時間変化について実験値と理論値を比較して, そ の罗当性を検証した。さらに，浮遊機構のモデルに従って，粗面上の粒子の浮遊限界を明らかにした。

今後, 浮遊機構のモデルに確率的な検討を加えて, 浮遊砂量の算定式を求めていきたい。 最後に, 本実験及び資料整理に御協力して頂いた，京都大学防災研究所技官吉田義則氏に謝意を表します。

1 ）芦田和男, 藤田正治 : 粗面上の粒子の浮遊機構と浮遊限界に関する研究, 京都大学防災研究所年報, 第 26 号 B $-2,1983$.

2) Grass, A. J. : Structural features of turbulent flow over smooth and rough boundaries, J. Fluid. Mech., Vol. 50, 1971, pp. $233 \sim 255$

3 ）䄥津家久：開水路流の乱流構造に関する基礎的研究, 京都大学学位論文, 昭. 52, p. 72.

4) 中川博次, 穪津家久：せん断乱流の bursting 現象とその物理モデル，第 22 回水理講演会論文集, 1978 , pp. $29 \sim 36$

5 ）芦田和男, 岡部健士, 藤田正治：粒子の浮遊限界と浮遊砂量に関する研究, 京都大学防災研究所年報, 第 25 号 B $-2 ， 1982$. 